\title{
ANALISIS KINERJA SISTEM BLUETOOTH PADA PHYSICAL LAYER UNTUK KOMUNIKASI SUARA TANPA KABEL
}

\author{
Robby Aris Cahyadi ${ }^{1}$, Heroe Wijanto ${ }^{2}$, Nachwan Mufti Adriansyah ${ }^{3}$ \\ Jurusan Teknik Elektro Sekolah Tinggi Teknologi Telkom, Bandung

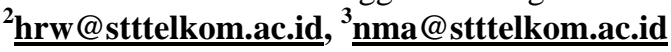

\begin{abstract}
Abstrak
Kehadiran beberapa teknologi radio seperti Bluetooth dan W-LAN IEEE 802.11b yang beroperasi pada pita frekuensi 2,4 GHz akan menimbulkan interferensi sinyal yang berakibat menurunnya kinerja secara signifikan ketika tergelar di lingkungan yang sama atau berdekatan. Pada penelitian ini akan didesain sistem physical layer pada protokol Bluetooth yang meliputi radio layer dan baseband layer. Dari model tersebut, kinerja Bluetooth pada physical layer dianalisis untuk komunikasi suara dengan jenis paket HV1, HV2 dan HV3, yaitu pada hubungan antara mobile phone dengan headset. Dari evaluasi terhadap kinerjanya terlihat sistem dapat mencapat syarat batas maksimum BER $10^{-3}$ untuk komunikasi suara digital pada kanal AWGN.
\end{abstract}

Kata kunci: Bluetooth Physical Layer, paket HV1-HV2-HV3, GFSK Frequency Hopping, CDMA, interferensi IEEE 802.11b

\begin{abstract}
The emergence of several radio technologies like Bluetooth and W-LAN IEEE 802.11b worked on the frequency of $2,4 \mathrm{GHz}$ will cause signal interference. This results in significant decrease of performance if they were in the same or near environment. Through this research, physical layer on Bluetooth protocol, consisting of radio layer and baseband layer, will be designed. Using the model, the performance of Bluetooth physical layer for voice communication with packet types HV1, HV2, and HV3 would be analyzed in a link between mobile phone and headset. The performance will reveal the system could reach the maximum limit requirement $\left(B E R=10^{-3}\right)$ for digital voice communication in the AWGN channel.
\end{abstract}

Keywords: Bluetooth Physical Layer, HV1-HV2-HV3 packet, GFSK Frequency Hopping, CDMA, IEEE 802.11b inteference

\section{Pendahuluan}

Bluetooth merupakan sistem komunikasi radio jarak dekat yang ditujukan untuk menggantikan kabel sebagai penghubung antar-perangkat portable dan atau antar-perangkat elektronik. Keunggulan Bluetooth antara lain robustness (ketahanan yang baik, seperti terhadap interferensi), perangkat yang tidak kompleks, daya yang rendah dan biaya murah.

Bluetooth beroperasi di pita frekuensi $2,4 \mathrm{GHz}$ yang merupakan pita unlicensed ISM. Penggunaan frekuensi hopping pada transceiver digunakan untuk mengurangi terjadinya interferensi dan fading. Untuk mengurangi kompleksitas pada transceiver digunakan sistem modulasi binary. Bluetooth memiliki simbol rate $1 \mathrm{Msymbol} / \mathrm{s}$ dengan panjang tiap slot $625 \mathrm{~ms}$. Untuk transmisi full duplex digunakan skema Time-Division Duplex (TDD). Tiap-tiap kanal membawa informasi berupa paketpaket. Setiap paket yang dikirimkan memiliki frekuensi hop yang berbeda. Protokol Bluetooth menggunakan kombinasi circuit switching dan packet switching. Slot dapat digunakan untuk sistem komunikasi sinkron atau asinkron, baik untuk data maupun voice. Kanal voice mendukung $64 \mathrm{kbps}$ kanal (voice) yang sinkron pada setiap arah. Kanal asinkron dapat mendukung maksimal $723.2 \mathrm{kbps}$ asimetrik (dan sampai $57.6 \mathrm{kbps}$ pada arah sebaliknya) atau $433.9 \mathrm{kbps}$ simetris.

\section{Struktur Protokol Bluetooth}

Pada Gambar 1 diperlihatkan struktur layer pada protokol Bluetooth.

\subsection{Format Paket}

Secara umum format paket terdiri atas tiga bagian, yaitu : Access Code (72 bit), Header (54 bit), Payload (0 - 2745 bit), masing-masing ditunjukkan pada Gambar 2, 3, dan 4. Access Code berfungsi untuk sinkronisasi, kompensasi DC offset dan identifikasi. Header berfungsi sebagai informasi link control yang terdiri dari :

-AM_ADDR : 3- bit alamat aktif Bluetooth

- ARQN : 1-bit indikasi acknowledge

- SEQN : 1-bit sequence number

- HEC : 8-bit header error check

- TYPE : 4-bit kode tipe paket

- FLOW : 1-bit flow control 


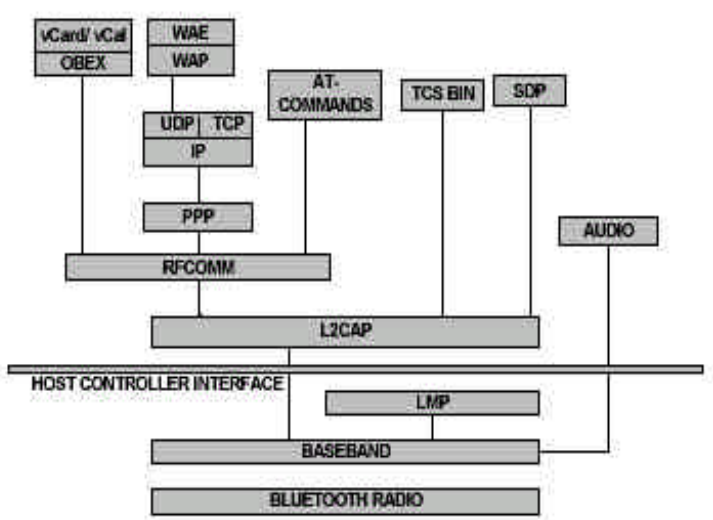

Gambar 1. Struktur Bluetooth Layer

\begin{tabular}{|c|c|c|c|}
\hline LSB 72 & 54 & 0.2745 & MSB \\
\hline $\begin{array}{c}\text { ACCESS } \\
\text { CODE }\end{array}$ & HEADER & PAYLOAD & \\
\hline
\end{tabular}

Gambar 2. Format Paket Bluetooth

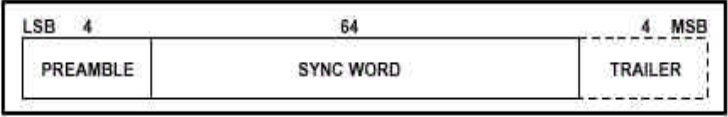

Gambar 3. Format Paket Access code

\begin{tabular}{|l|c|c|c|c|c|}
\hline LSB 3 & 4 & 1 & 1 & 8 & MSB \\
\hline AM ADDR & TYPE & FLOWARQN SEQN & & HEC \\
\hline
\end{tabular}

Gambar 4. Format Paket Header

Keseluruhan header berjumlah 18 bit ditambah dengan encoding FEC hingga berjumlah 54 bit, sedangkan untuk payload tergantung dari jenis paketnya, baik itu untuk suara atupun data yang memiliki jumlah payload yang berbeda-beda.

\subsection{Jenis Saluran Fisik Bluetooth}

Antara master dan slave memiliki hubungan dengan dua jenis saluran, yaitu:

- Saluran Synchronous Connection-Oriented (SCO)

- Saluran Asynchronous Connection-Less (ACL)

Saluran SCO adalah hubungan point to point antara master dan slave tunggal dalam piconet dan menggunakan circuit swicthed. Sedangkan saluran ACL menggunakan hubungan point to multi point antara master dan banyak slave dalam piconet dan menggunakan packet switched.

Jenis paket pada saluran SCO menggunakan jalur synchronous SCO. Paket tersebut tidak menyertakan CRC dan tidak ada pengiriman ulang. Paket SCO di-route melalui port sinkron I/O (voice). Paket SCO terdapat tiga jenis: HV1, HV2, HV3.

\section{Paket HV1}

HV singkatan dari Highquality Voice. Paket HV digunakan untuk transmisi suara dan sinkronous data. Untuk Paket HV tidak pernah terjadi pengiriman ulang. Paket HV1 membawa 10 byte informasi. Byte informasi itu disertai $1 / 3$ FEC rate. Tanpa CRC dan payload untuk header, panjang payload-nya 240 bits. Paket ini membawa informasi suara dengan $1.25 \mathrm{~ms}$ pada rate $64 \mathrm{kbps}$, sehingga dikirimkan setiap dua time slot $(\mathrm{TSCO}=2)$.

\section{Paket HV2}

Paket HV2 membawa 20 byte informasi. Byte informasi itu disertai 2/3 FEC rate. Tanpa CRC dan payload untuk header, panjang payload-nya 240 bits. Paket ini membawa informasi suara dengan $2.5 \mathrm{~ms}$ pada rate $64 \mathrm{kbps}$, sehingga dikirimkan setiap empat time slot $(\mathrm{TSCO}=4)$.

\section{Paket HV3}

Paket HV1 membawa 10 byte informasi. Tanpa CRC, FEC dan payload untuk header, panjang payload-nya 240 bits. Paket ini membawa infomasi suara dengan $3.75 \mathrm{~ms}$ pada rate $64 \mathrm{kbps}$. sehingga akan dikirimkan setiap enam time slot $(\mathrm{TSCO}=6)$.

\subsection{Metode Koreksi Error}

Terdapat tiga macam skema koreksi error pada Bluetooth, yaitu: $1 / 3$ rate $\mathrm{FEC}, 2 / 3$ rate FEC, dan skema ARQ untuk data. Tujuan skema FEC pada payload data adalah untuk mengurangi banyaknya retransmisi. Namun akibatnya diperlukan ruang untuk FEC sehingga akan menambah overhead dan akan mengurangi throughput. Header paket selalu menggunakan $1 / 3$ rate FEC.

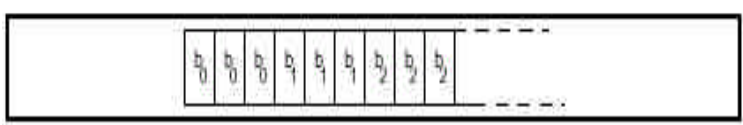

Gambar 5. Skema FEC 1/3 Rate

\section{- FEC CODE: RATE $1 / 3$}

FEC tipe ini paling sederhana, yaitu hanya berupa pengulangan 3 kali setiap bit, seperti diperlihatkan di Gambar 5. Penggunaannya dilakukan pada setiap header dan jenis paket HV1.

\section{- FEC CODE: RATE $2 / 3$}

Skema ini menggunakan $(15,10)$ Shortened Hamming Code, dengan generator polynomial $g(D)=(D+1)(D 4+D+1)$. Kode ini dapat mengoreksi semua error tunggal dan mendeteksi semua error pada setiap codeword. FEC 2/3 rate digunakan pada paket DM, paket DV, paket FHS dan paket HV2.

\section{- SKEMA ARQ}

Skema Automatic Repeat reQuest digunakan untuk tipe paket DM, DH dan field data paket DV, dikirimkan dan di retransmitkan kembali sampai menerima acknowledgement. Untuk menentukan apakah payload benar atau tidak, ditambahkan kode cyclic redundancy check (CRC) pada paket. Skema ARQ hanya bekerja pada payload yang memiliki CRC. Paket header dan voice payload tidak menggunakan skema ini. 


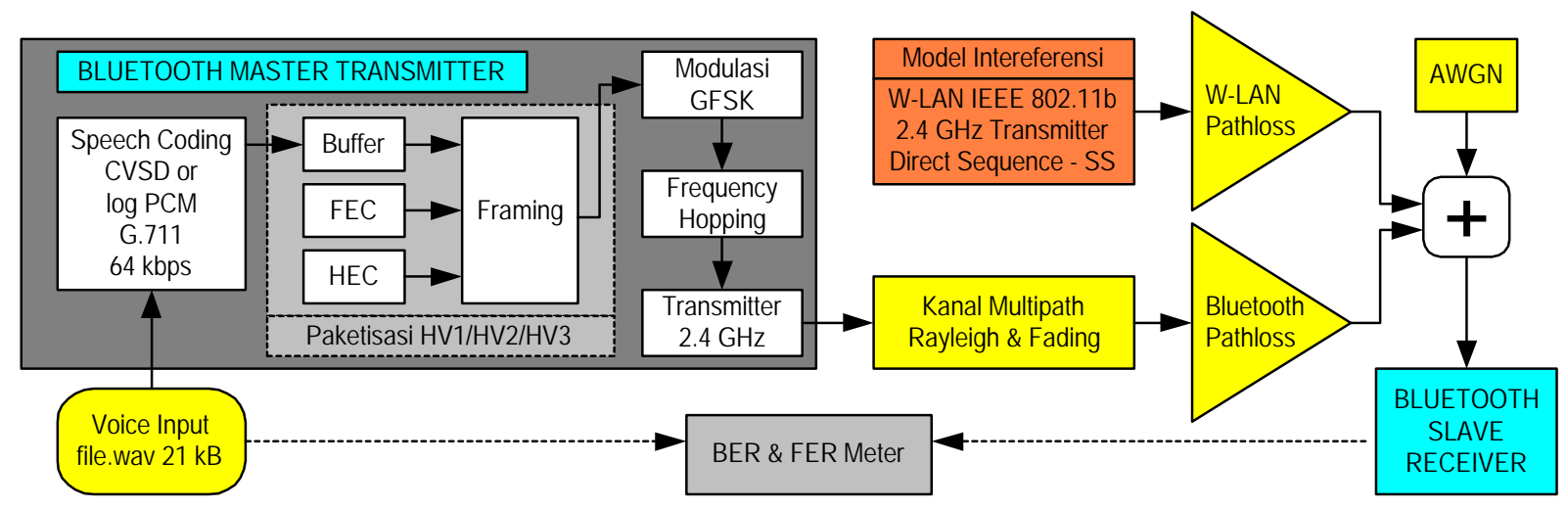

Gambar 6. Model Sistem Bluetooth untuk Komunikasi Paket Suara HV1/HV2/HV3

\section{Pemodelan Sistem}

Model sistem mencakup proses transmisi suara pada Bluetooth, yaitu komunikasi antara mobile phone dengan headset. Komunikasi suara pada Bluetooth menggunakan jenis paket HV1, HV2 dan HV3 yang telah dibahas di bagian 2.2. Perangkat Bluetooth dapat menjadi master atau slave. Master adalah yang memulai inisiatif melakukan hubungan dengan perangkat Bluetooth lainnya sebagai slave.

Skenario yang dilakukan pada pengujian ini antara lain dengan mengirimkan file wave (untuk simulasi ini besarnya file $21 \mathrm{kB}$ ). File wave ini akan dilewatkan melalui kondisi kanal bermacam-macam. Pengujian ini dilakukan pada kondisi kanal berubah dari kondisi ideal yang diharapkan tanpa pengaruh apapun hingga pada kondisi kanal terburuk yang dipengaruhi oleh interferensi W-LAN 802.11b Direct Sequence Spread Spectrum dan pengaruh dari sesama pengguna Bluetooth, pengaruh Additive White Gaussian Noise (AWGN) dan Path Loss.

Pada Gambar 6 diperlihatkan model sistem Bluetooth untuk komunikasi paket suara. Model tersebut terdiri dari master transmitter, kanal radio, sumber interferensi W-LAN IEEE $802.11 \mathrm{~b}$, slave receiver dan pengukuran error (BER dan FER). pengamatan juga dilakukan terhadap bentuk sinyal fungsi waktu, spektrum frekuensi dan spektogram dari sinyal Bluetooth dengan sinyal W-LAN IEEE 802.11b. Model tersebut dibuat berdasarkan suatu pemrosesan frame. Selain itu, telah digunakan pula pemodelan operasi blok-blok sistem forward error correction (FEC) dan cyclic redundancy checks (CRC) dengan panjang frame data yang tetap.

\subsection{Master Transmitter}

Subsistem transmitter terdiri dari voice input, speech coding, buffering, framing, HEC, FEC, modulasi, dan frekuensi hopping. Whitening yang dihilangkan dapat ditambahkan dengan Scrambling.

\subsection{Koding Suara CVSD}

Pada standar Bluetooth terdapat dua jenis pengkodean suara yaitu Continuous Variable Slope
Decoding (CVSD) dan 64 kbps log PCM (G.711). Pada model ini digunakan digunakan jenis CVSD. Blok Wavread block membawa sinyal $8 \mathrm{kHz}$ signal dari "file.wav", kemudian sinyal tersebut diinterpolasikan hingga $64 \mathrm{kHz}$ untuk dilakukan pengkodean. CVSD speech coder mengkodekan setiap sample dengan bit tunggal mnggunakan skema koding diferensial, dimana mengirim 1 bit jika sample suara bertambah dari nilai sebelumnya dan bit 0 jika berkurang. Skema ini tahan terhadap kesalahan bit, dengan parameter sama dengan pada standar Bluetooth. Keluaran coder adalah 64 kbps stream, yang akan di-buffer kedalam bentuk frame sebesar 240 bit, sama dengan $3.75 \mathrm{~ms}$ suara.

\subsection{HEC, FEC and Framing}

Payload 240-bit untuk suara diperbesar dengan tambahan kontrol informasi, sebagaimana telah diperlihatkan pada Gambar 3. Telah pula diperlihatkan pada Gambar 2 rangkaian dari kode akses 72-bit, header 54-bit, dan payload 240-bit, sehingga menjadi 366-bit frame. Header 54-bit berisikan pengulangan FEC yang sederhana dari 18bit informasi header dan bit header error check (HEC). HEC adalah CRC 8-bit yang dihitung dari informasi header 10-bit. Informasi header berisi bitbit penting di antaranya mengenai alamat slave, jenis paket, dan status bit.

\subsection{Modulasi dan Frekuensi Hopping}

Sebanyak 366 bit data dikirimkan pada dengan data rate $1 \mathrm{Mbps}$ dan dimodulasikan secara GFSK. GFSK secara efektif mengirimkan sinyal $+150 \mathrm{kHz}$ relatif terhadap carrier untuk bit 1 , atau juga sinyal $-150 \mathrm{kHz}$ untuk bit 0 . Dengan 100 sample per symbol keluaran dari blok modulator ini, dihasilkan bandwidth sempit dengan sinyal baseband kompleks terpusat sekitar $0 \mathrm{~Hz}$ dengan sample rate sebesar $0,01 \mathrm{~ms}$ (atau $\pm 50 \mathrm{Mhz}$ range frekuensi). Sample ini disimulasikan dalam bentuk frame dari 62500 sample sehingga slot rate-nya sebesar $625 \mathrm{~ms}$.

Untuk menghindari interferensi dengan perangkat yang menggunakan frekuensi ISM lainnya, Bluetooth mengirimkan frekuensi carrier 
berbeda-beda pada tiap slotnya. Ini didapat dengan mengalikan sinyal baseband dengan salah satu dari kemungkinan 79 frekuensi yang berada pada cakupan $\pm 39 \mathrm{MHz}$. Sinyal carrier yang dihasilkan pada model ini menggunakan blok baseband MFSK 79 simbol dengan jarak antar symbol $1 \mathrm{MHz}$. Jika frekuensi hopping bernilai 0 , maka dihasilkan sinyal sinusoidal -39 MHz kompleks. Jika hopping bernilai 1, maka dihasilkan $-38 \mathrm{MHz}$, dan seterusnya.

Untuk transmisi suara hanya digunakan setiap 6 slot. Modulator akan berfungsi dalam melakukan setting slot rate sehingga diperlukan subsistem enable untuk mengaktifkan setiap 6 sample misalnya (atau pada SCO rate). Akhirnya, daya sinyal yang dikirimkan diatur pada $0 \mathrm{dBm}(1 \mathrm{~mW})$. Pengaruh dari RF stage seperti mixing ke $2.4 \mathrm{GHz}$ dan filtering, tidak dimasukkan dalam model.

\section{Hasil Simulasi dan Percobaan}

\subsection{Kinerja Bluetooth Terkontaminasi AWGN}

Dari grafik pada Gambar 7 di atas terlihat syarat batas minimum BER untuk komunikasi digital $\left(\mathrm{BER}=10^{-3}\right)$ dapat dicapai pada $\mathrm{Es} / \mathrm{No}=3 \mathrm{~dB}$ untuk tipe paket HV1, Es/No $=4 \mathrm{~dB}$ untuk HV2, dan Es/No $=4 \mathrm{~dB}$ untuk HV3. Dan untuk bebas bit error $(\mathrm{BER}=0)$ dicapai pada kondisi $\mathrm{Es} / \mathrm{No}=10 \mathrm{~dB}$ untuk tipe paket HV1, Es/No = $11 \mathrm{~dB}$ untuk HV2, dan $\mathrm{Es} / \mathrm{No}=11 \mathrm{~dB}$ untuk HV3.

Sedangkan dari grafik pada Gambar 8 terlihat untuk kondisi bebas frame error $(\mathrm{FER}=0)$ dicapai pada $\mathrm{Es} / \mathrm{No}=0.8 \mathrm{~dB}$ untuk $\mathrm{HV} 1$, Es/No $=1.2 \mathrm{~dB}$ untuk HV2, dan Es/No = $0.8 \mathrm{~dB}$ untuk HV3.

Tipe paket HV1 terlihat lebih baik diikuti HV2 dan HV3 dikarenakan penggunaan metode Forward Error Correction. Namun dari evaluasi mengenai frame error yang terjadi, hampir seluruh keadaan tidak memberikan frame error atau sama dengan nol, kecuali untuk keadaan kualitas sinyal yang kurangdari pada $\mathrm{Es} / \mathrm{No}=1.5 \mathrm{~dB}$.

\subsection{Kinerja Sistem Bluetooth Terinterferensi Antar-User Bluetooth}

Pada simulasi ini masing-masing percobaan dilakukan hanya sampai 15 piconet Bluetooth. Dari Gambar 9 dan Gambar 10 terlihat bahwa semakin banyak piconet Bluetooth dalam suatu ruangan, maka kinerja sistem akan menurun yang ditunjukkan oleh peningkatan Raw BER. Walaupun BER cukup besar dan tidak memenuhi $10^{-3}$, namun integritas frame yang dihasilkan cukup baik, sehingga suara yang dihasilkan masih dapat didengar dengan baik.

Dari hasil yang diperoleh untuk seluruh tipe, HV1 memiliki kinerja yang terbaik, diikuti oleh HV2 dan HV3. Penurunan kinerja hingga 15 user sebesar $1.2 \%$ untuk HV1, $1.6 \%$ untuk HV2, dan 4.7\% untuk HV3. Untuk komunikasi point-tomultipoint atau sebaliknya dapat dilakukan hingga 8

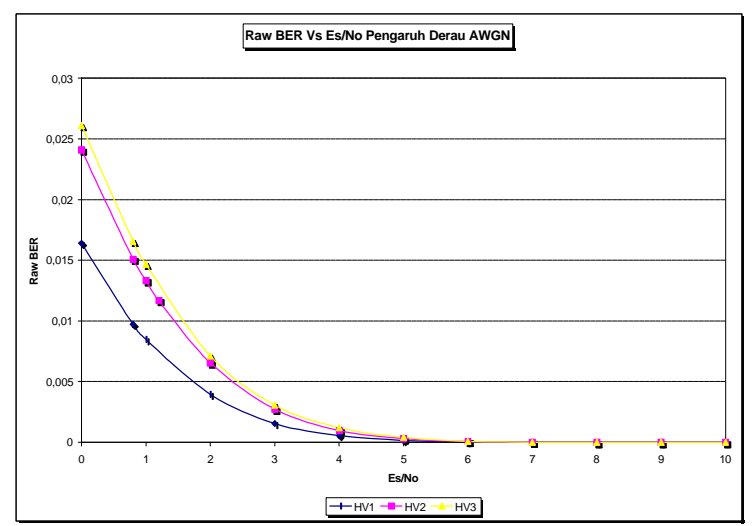

Gambar 7. BER terhadap Es/No

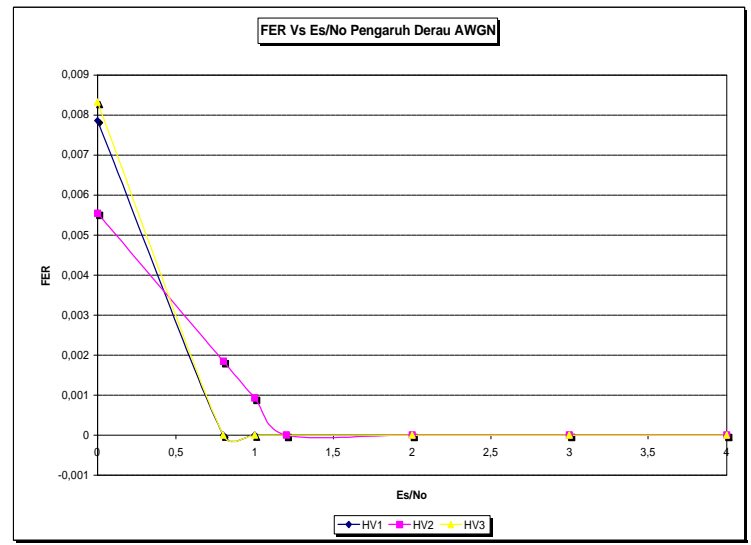

Gambar 8. FER terhadap Es/No

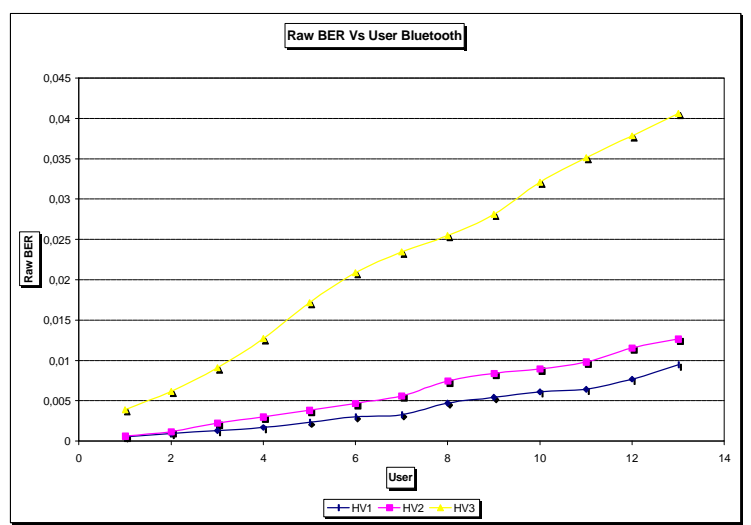

Gambar 9. Raw BER vs Interferensi Piconet

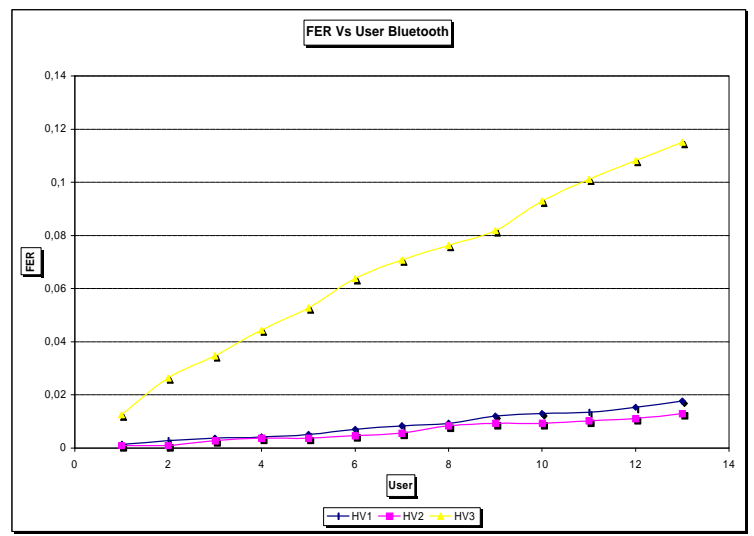

Gambar 10. FER vs Interferensi Piconet 
user Bluetooth, 1 user sebagai master dan 7 lainnya sebagai slave dalam satu piconet. Hasil simulasi bisa mencapai 15 piconet ( 15 × $8=120$ user Bluetooth).

Tabel 1. Perbandingan pada saat 15 piconet

\begin{tabular}{|c|r|c|c|l|l|}
\hline Tipe & $\begin{array}{c}\text { Bit } \\
\text { Error }\end{array}$ & BER & $\begin{array}{c}\text { Frame } \\
\text { Error }\end{array}$ & \multicolumn{1}{|c|}{ FER } & \multicolumn{1}{|c|}{ MSE } \\
\hline HV1 & 9733 & 0.01231 & 47 & 0.02175 & 0.00181 \\
\hline HV2 & 6125 & 0.01548 & 14 & 0.01295 & 0.0019 \\
\hline HV3 & 12380 & 0.04691 & 95 & 0.1318 & 0.0013 \\
\hline
\end{tabular}

Tabel 1 ditampilkan untuk lebih menunjang analisis mengenai frame error rate, total error yang terjadi, dan total frame error dari ketiga tipe pada kondisi 15 user Bluetooth. Tipe HV2 memiliki kinerja terbaik dari tipe lainnya, baik bit error, BER, frame error, FER maupun MSE.

Kinerja sistem Bluetooth yang terinterferensi oleh sesama pengguna Bluetooth untuk tipe HV1, HV2 dan HV3 mengalami degradasi, suara yang dihasilkan dapat didengar, namun berkualitas buruk.

\subsection{Kinerja Sistem Bluetooth \\ Terinterferensi WLAN IEEE 802.11b.}

Dari grafik-grafik untuk BER dan FER dari ketiga tipe pada Gambar 10 dan Gambar 11, ditunjukkan nilai-nilai yang memiliki selisih tidak berbeda jauh. Pengaruh interferensi IEEE 802.11b berpengaruh besar dibandingkan pengaruh dari halhal yang telah dibahas di atas. Tidak terlihatnya pengaruh penggunaan FEC disebabkan karena error yang terjadi bersifat bursty atau terjadi lebih dari satu error. Sedangkan FEC $1 / 3$ dan $2 / 3$ hanya mampu mendeteksi dan mengkoreksi satu error saja.

Tabel 2. Perbandingan pada saat paket rate 999

\begin{tabular}{|l|c|c|c|c|c|}
\hline Tipe & $\begin{array}{c}\text { Bit } \\
\text { Error }\end{array}$ & BER & $\begin{array}{c}\text { Frame } \\
\text { Error }\end{array}$ & FER & MSE \\
\hline HV1 & 66660 & 0.08428 & 456 & 0.211 & 0.001349 \\
\hline HV2 & 37000 & 0.09351 & 244 & 0.2257 & 0.0014055 \\
\hline HV3 & 22700 & 0.08603 & 153 & 0.2122 & 0.0011949 \\
\hline
\end{tabular}

Pada Table 2 diperlihatkan nilai BER dan FER ketiga jenis paket pada rate paket 999. Data tersebut menunjukkan bahwa throughput semakin berkurang dengan penambahan payload, karena paket frame yang dikirimkan akan lebih banyak dibandingkan dengan yang memiliki sedikit payload. Pada kondisi trafik yang padat, penentuan FEC yang tepat sangat menentukan keberhasilan paket yang sukses.

\subsection{Analisis Probabilitas Paket Error}

Setiap pengiriman satu paket IEEE 802.11b dapat terjadi overlap dua sampai tiga paket Bluetooth burst. Probabilitas terjadinya collision adalah sebagai berikut:

$$
\begin{aligned}
\mathrm{Pc} 2 & =1-(1-(\mathrm{WR} /(\mathrm{WR} \times \mathrm{Nc})))^{2} \\
& =1-(1-(22 \mathrm{MHz} /(1 \mathrm{MHz} \times 79)))^{2} \\
& =47,9 \%
\end{aligned}
$$

$$
\begin{aligned}
\mathrm{Pc} 3 & =1-(1-(\mathrm{WR} /(\mathrm{WT} \times \mathrm{Nc})))^{3} \\
& =62,4 \%
\end{aligned}
$$

Dari hasil di atas, probabilitas collision ketika terjadi dua paket Bluetooth sebesar Pc2 $=47,9 \%$, sedangkan untuk tiga paket overlap lebih besar lagi, yaitu Pc3 $=62,4 \%$. Dengan packet rate makin besar, maka meningkat pula peluang terjadinya collision pada kanal tersebut, sebagaimana ditunjukkan pada peningkatan nilai BER dan FER secara signifikan.

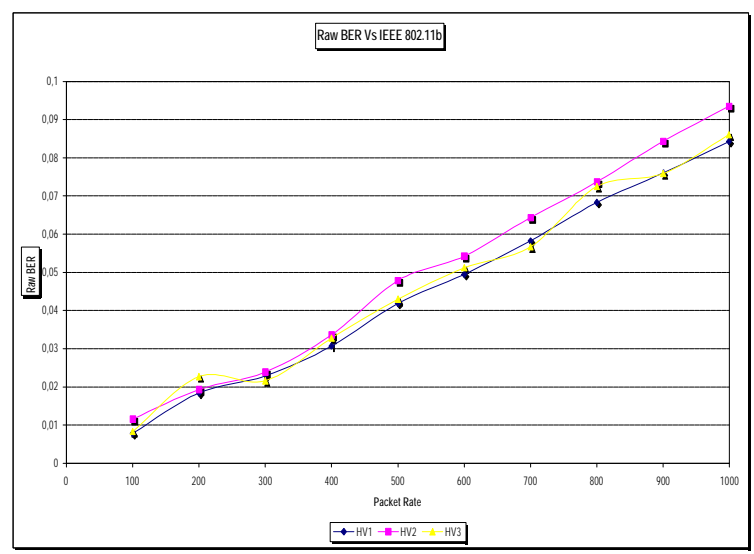

Gambar 10. Raw BER Vs interferensi IEEE 802.11b

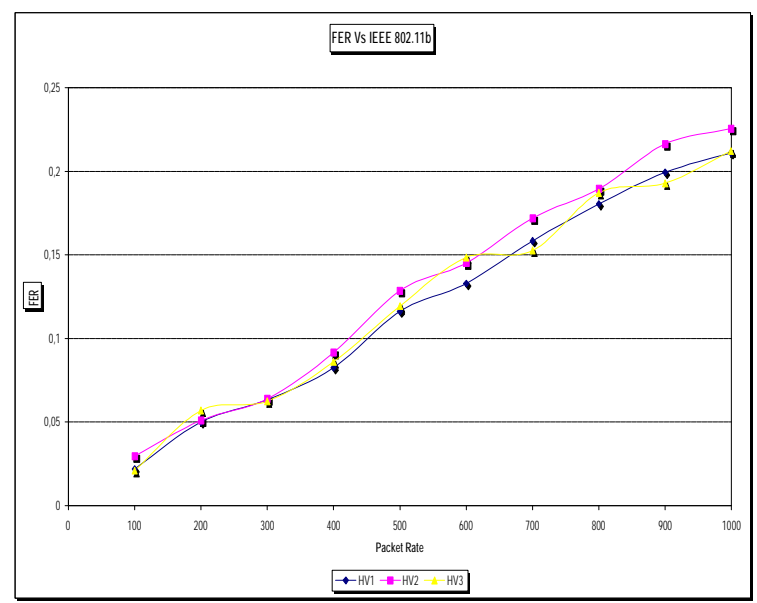

Gambar 11. FER Vs interferensi IEEE 802.11b

\subsection{Kinerja Sistem WLAN IEEE 802.11b Terinterferensi oleh Bluetooth}

Pengaruh interferensi Bluetooth terhadap kinerja sistem IEEE 802.11 b berdasarkan perubahan jarak antara kedua sistem telah diperoleh dari data percobaan [3]. Topologi kedua jaringan dalam suatu ruang diperlihatkan pada Gambar 12. Hasil percobaan tersebut diperlihatkan pada Gambar 13.

Hasil percobaan di atas menunjukkan semakin dekat jarak Access Point WLAN IEEE 802.11b dengan Bluetooth, maka probabilitas paket error semakin besar. Pada Gambar 13 ditunjukkan jarak aman untuk menghindari terjadinya interferensi adalah lebih dari 5 meter. Suatu perencanaan jaringan harus memenuhi syarat jarak aman tersebut, apabila dalam suatu lingkungan terdapat beberapa pengguna Bluetooth dan WLAN IEEE 802.11b. 


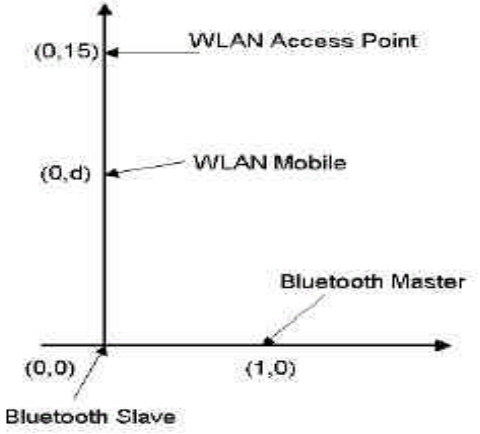

Gambar 12. Topologi Jaringan Bluetooth dan WLAN

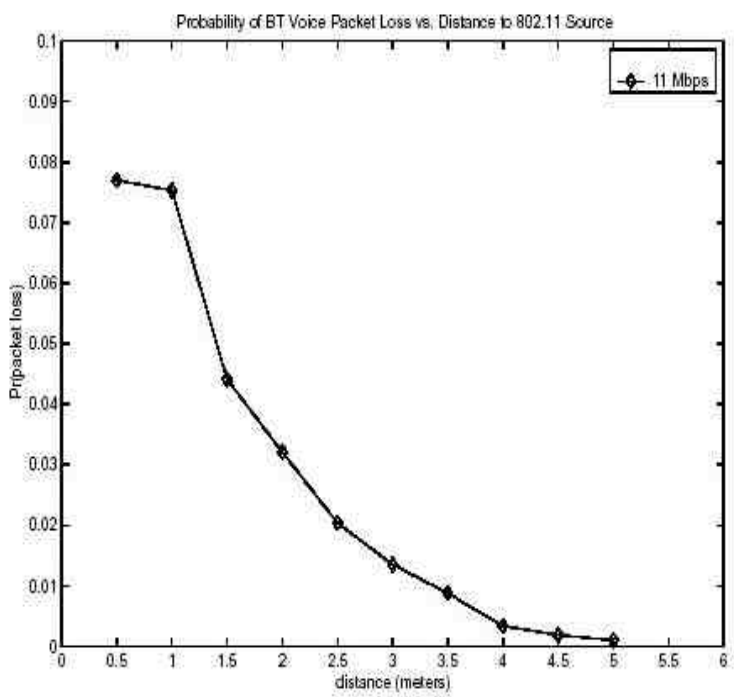

Gambar 13. Probabilitas Error IEEE 802.11b terhadap Jarak ke Bluetooth

\section{Kesimpulan}

Dari pembahasan di atas, dapat diambil kesimpulan bahwa Pada kanal AWGN, BER maksimum untuk komunikasi suara digital $\left(\mathrm{BER}=10^{-3}\right)$ dicapai pada $\mathrm{Es} / \mathrm{No}=3 \mathrm{~dB}$ untuk tipe paket $\mathrm{HV} 1$, pada $\mathrm{Es} / \mathrm{No}=4 \mathrm{~dB}$ untuk $\mathrm{HV} 2$, dan Es/No $=4 \mathrm{~dB}$ untuk HV3. Jadi HV1 memiliki kinerja terbaik, diikuti HV2 dan HV3. Pada simulasi dapat dicapai 15 piconet $(15 \times 8=120$ user Bluetooth) dalam satu ruangan. Ini menunjukkan kapasitas sistem yang cukup besar. Semakin besar packet rate W-LAN IEEE $802.11 \mathrm{~b}$, semakin besar pula BER dan FER pada Bluetooth. Interferensi WLAN IEEE 802.11 b berpengaruh kuat pada kinerja sistem Bluetooth. Semakin dekat jarak W-LAN IEEE 802.11b dengan Bluetooh, semakin besar pula probabilitas error pada Bluetooth maupun pada WLAN IEEE 802.11b. Jarak aman untuk menghindari terjadinya saling interferensi antara kedua sistem adalah lebih dari 5 meter. Penggunaan FEC dapat meningkatkan perbaikan kinerja sistem Bluetooth.

Sangat menarik diteliti lebih lanjut untuk semua tipe paket Bluetooth, baik suara maupun data, untuk melihat kinerja sistem secara menyeluruh. Hendaknya dibuat kajian lebih lengkap pada kondisi sebaliknya, yaitu bagaimana pengaruh interferensi
Bluetooth terhadap degradasi kinerja WLAN IEEE 802.11 b. Perlu kajian lebih lanjut untuk kondisi kanal yang lebih representatif, mempertimbangkan terjadinya fading, perubahan jarak interferensi, dan perbedaan pola radiasi gelombang dari kedua sistem Bluetooth dan WLAN IEEE 802.11b.

\section{Daftar Pustaka:}

[1] Frainberg, M. and D. J. Goodman. Maximizing Performance of a Wireless LAN In The Presence of Bluetooth.

[2] Freeman, R. L. 1991. Telecommunications Transmission Handbook 3 rd Edition, New York. John Wiley \& Sons. Inc.

[3] Golmie, N. and N. Chevrollier. Techniques To Improve Bluetooth Performance In Interference Environments

[4] Golmie, N., R. E. Van Dyck, and S. Soltanian. Interference of Bluetooth and IEEE 802.11: Simulation Modelling and Performance Evaluation

[5] http://www.bluetooth.com

[6] http://www.bluetoothcentral.com

[7] http://www.homeRF.org

[8] IEEE 802.11 Wireless LAN Standards

[9] Kontakos N. P. and Pollard J. K. Bluetooth RF Layer Performance Evaluation

[10] Mim, R. How Bluetooth Interference Impacts Wireless LANS

[11] Shorey, R. and B. A. Miller. The Bluetooth Technology: Merits and Limitations

[12] Spasojevic, Z. and J. Burns. Performance Comparison Of Frequency Hopping And Direct Sequence Spread Spectrum Systems In The 2.4 GHz Range

[13] Specifications Of The Bluetooth System Version 1.1 - Core. Feb 2001 